\title{
WORLD SHIPBUILDING: DRIVING FORCES AND RELEVANT DEVELOPMENT VECTORS
}

\author{
Volodymyr Parsiak ${ }^{1}$, Olena Zhukova ${ }^{2}$, Katerina Parsiak ${ }^{3}$
}

\begin{abstract}
The purpose of the paper is to find out under the influence of which external impulses and according to which vectors events in the field of shipbuilding are taking place in our time. Concentrating attention on them, the authors sought to provide shipbuilders-practitioners with guidelines useful for making weighted and sometimes fateful business decisions. The conducted research seems timely from the viewpoint of the formation by the owners and management of the development strategy of domestic shipyards. Especially those related to the "new wave." In the overwhelming majority, it is represented, paradoxically, by small and mediumsized enterprises. In recent years, they have been striving to find their own place in the international market for engineering, construction, repair, conversion, operation, and recycling of products whose line makes the structure of the chosen industrial specialization. The fact that the prospects for this business, despite the known difficulties, are optimistic is evidenced by the dynamics of the absolute volume of cargo transportation by sea and the construction of new vessels it has caused. Methodology. The performed generalizations are based on the analytical processing and systematization of data obtained by the authors from available information sources. As a result, substantiation of the arguments confirming the formulated working hypothesis regarding fundamental changes in the global shipbuilding - a key type of marine economic activity - has been obtained. Among its many features - a high level of competition, in which more and more new rivals are drawn. The study outlines the factors, under the influence of which the identified metamorphoses occur. This creates the prerequisites for identifying causal relationships between the first and second ones. In particular: humanity's facing with the realities of the Fourth Industrial Revolution, signs of which are easily detected in shipbuilding; awareness by governments, socially responsible business, the public of the fatal consequences of neglecting environmental safety, affecting the natural environment and people employed in the maritime industry or residing in its area; advances in the sectoral international division of labour, accompanied by the emergence of new shipbuilding centres; the rising cost of marketing and building ships and the desire of shipowners to get an effect on the scale of the facilities used. At the same time, obstacles that occur along the way are identified. Practical implications. In support of the conclusions, we analyse the experience of leading enterprises, which serve as an example for imitation and deserve further development. They are not limited solely to technical and technological innovations but find the use of new organizational forms of mobilization of accumulated potentials. Among them are shipbuilding clusters. Turning to their creation, the initiators seek to strengthen the competitive positions of participants in developed segments and actively form new promising markets. Value/originality. As a result of systematization of the key areas of the drift of world shipbuilding, an information platform has been created, based on which shipyard management is able to foresee the future of the business under its care.
\end{abstract}

Key words: economy, shipbuilding, maritime economy, Industry 4.0, ecological safety, scale effect, international specialization.

JEL Classification: F20, L10, L19

\footnotetext{
Corresponding author:

${ }^{1}$ Admiral Makarov National University of Shipbuilding, Ukraine.

E-mail: volodymyr.parsyak@nuos.edu.ua

ORCID: https://orcid.org/0000-0002-4756-8977

${ }^{2}$ Admiral Makarov National University of Shipbuilding, Ukraine.

E-mail: eyzhukova@gmail.com

ORCID: https://orcid.org/0000-0001-8966-8354

${ }^{3}$ Kherson Branch of Admiral Makarov National University of Shipbuilding, Ukraine.

E-mail: parsyak.katerina@gmail.com

ORCID: https://orcid.org/0000-0001-7523-9065
} 


\section{Introduction}

Shipbuilding - one of the oldest and extremely competitive types of maritime business, the relation of which in Ukraine is not indifferent. But if the authorities, individual officials, and party leaders only mention it in the context of the implementation of certain election measures (this is especially noticeable on the eve of 2019), then the business (mostly small and medium) proves the desire to preserve the maritime status of the state. It's not easy to do. Therefore, due to everyday troubles, owners and management do not always have time to verify corporate growth and development strategies with planetary vectors for advancing the initiated business.

Without their awareness, in the globalized world, as well as in the markets for complex engineering structures (vessels, ships, offshore mining platforms, wind power devices), any mistake leads to loss of market advantages, depletion of the portfolio of contracts with corresponding financial implications. There are many examples. It is the short-sightedness of the former leaders of the Black Sea Shipbuilding Plant, VAT "Shipbuilding Plant "Okean" (put up in August 2018 for sale after the announcement of its bankruptcy), the Plant named after 61 Communards along with unpretentious thinking of the leaders of the profile ministries led to the decline of the once-flowering industry. Only the aircraft carriers of the naval forces of China remind of its upsets. All of them (buildings or complete complexes) were built in the past at Ukrainian shipyards.

The following disgraces get a particularly bitter taste as well because they happen at a time when:

on average, during the launching ceremonies taking place on the staples, in slips and dry docks of enterprises scattered by the territories of all (except Antarctica) continents, a traditional bottle of champagne is annually smashed on boards of more than 1350 newly built vessels;

ninety percent of the world's commercial traffic is transported by sea. But the advantage of the vessels is not limited to this. Specially trained specialists also conduct industrial fishing and fish processing, provide artificial growth of live edible and decorative organisms, entertain travellers during cruises, run the underwater utility lines, conduct searches and evacuation of those who have suffered an accident, counteract attacks of pirates, explore and extract minerals, mobilize renewable energy sources, deprive the environment of pollution, are concerned with the arrangement of the coastal zone of the seas and inland reservoirs, etc.;

large and small shipowners are not tired of replenishing briefcases of ship order with new contracts so shipyards enthusiastically get down to work. So we must stop lag behind!

\section{Brief literature review}

It would not be fair to abstract from the workings of our predecessors. Some have devoted their publications to the clarification of the nature of economic cycles in world shipbuilding (Hossain, 2017; Nikiforov, 2011). Others highlight regional aspects of the issue (The statistics Portal, 2018; Grey, 2015). The annual reports of international organizations and specialized statistical databases have proved to be extremely useful (Shipbuilding Industry, 2017; Review of maritime transport, 2017). These and other publications are investigated by the authors with interest and attention. As a consequence, the results obtained are represented in Figure 1. Consider each component of the scheme in more detail.

\section{Integration of shipbuilding in the contexts of Industry 4.0}

A feature of the XXI century has become a series of transformations in the world economy, which under the German initiative have been called the Fourth Industrial Revolution (Industry 4.0). It is expected that it will obtain absolute domination in the industry of intellectual production based on digital systems, which through the Internet collect information and keep control of the supply chain throughout all stages of the product's lifecycle. The launched processes have not sidestepped such a high-tech activity as shipbuilding. In support of this hypothesis, we give a few arguments.

1. Distribution of systems of automatic control of

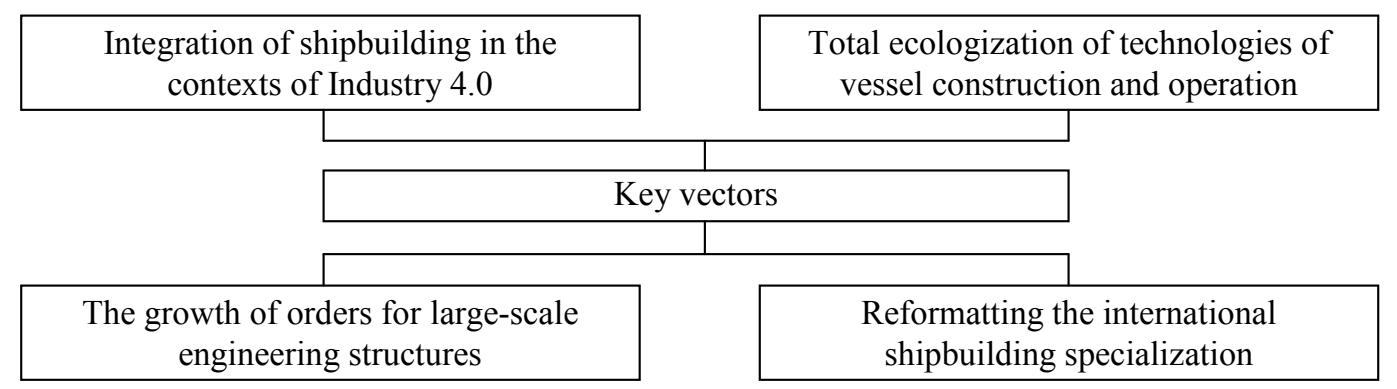

Figure 1. Development of world shipbuilding

Source: the author's generalization 
vessels and operations of cargo handling in ports. For example: computer navigation, global positioning of ships, automation of loading and unloading works. They allow, firstly, reducing the number of crews, dockers' crews and, secondly, increasing shipping safety and productivity of cargo terminals. The growth of the popularity of complex operating systems is due, among other things, to the explosive rise of container traffic. The software developed controls the flows of goods, port equipment in real time, plans to distribute containers to the warehouse area, control the work of trucks, trains arriving for or with cargo.

2. Development of new technologies for the design, construction, and operation of ships. In particular:

a) offering shipping companies a diverse range of products of various sizes thanks to the combination of standard hull fragments. This reduces the production cycle, simplifies the conversion of one or another part of the object during scheduled or unpredictable repairs; b) robotizing of production processes as a means of increasing their economic efficiency by reducing the cost of work and the limited involvement of staff to perform hazardous technological operations. An example is the South Korean Shipyard "Geoje" of Samsung Corporation, which uses robots in $68 \%$ of welding processes (Hodson, 2014). And where the presence of a worker is mandatory (during the construction of vessels, some operations cannot be automated in principle), they offer exoskeletons. These devices allow manipulating parts and knots weighing $100 \mathrm{~kg}$;

c) the coordination of many functions in order to accelerate the development and implementation of new products in the market that would satisfy the customer's idea of an acceptableprice-qualityratio.Amongthem, asappropriate,marketing (monitoring market needs, PR events, sales organization, including e-commerce), the timely order of an extremely wide range of component parts, metal, manufacture of ship structures from it and, of course, the search for sources of coverage of huge current costs.

For the industry concerned, given the competitive environment in which its enterprises operate, the duration of the construction of vessels, ships, drilling platforms (from a few months to several years), this is especially important. The response to the corrective request was the transfer to shipbuilders from the engineering bureaux of 3D models of the hull, its systems, and individual building sections arranged according to international standards.

Here, as never before, the technology of electronic information exchange becomes useful. Here are some of the many examples: CALS-technology Continuous Acquisition and Lifecycle Support, Design for Manufacture and Assembly, Design for Production, Kronodoc Solutions. They provide opportunities, firstly, for the processing of superfluous information flows, which tend to increase and improve the intensity; and secondly, to create, share, and distribute knowledge from available sources; thirdly, for rational distribution of employees' efforts and saving of funds due to the complete exclusion of paper from circulation (Parsyak, 2015).

\section{Total ecologization of technologies of vessel construction and operation}

It follows from the growing awareness of the need to prevent harmful emissions to the environment. This is not a trivial moralisation. According to scientists (CEEH, 2011), over the past few years, air pollution from international shipping has caused 50,000 premature deaths only in Europe. The fact is that because of the chemical reactions in the air, the exhaust gases from marine engines are converted into small particles and harmful aerosols. Together with black carbon, they fall into the lungs of people, from there - into the bloodstream, and then - into the internal organs, causing their disorder. This is a terrible price paid by mankind for the growth in shipping.

According to the concept of "environmental (blue) logistics" (Seroka-Stolka O., 2014), everyone concerned should take care of minimizing waste and contaminations in the supply chain that is under control. From this, shipyards should build energy-efficient vehicles. In particular, due to:

a) the transfer of main and auxiliary engines to alternative fuels. For example, liquefied gas. This will reduce the carbon dioxide emissions into the atmosphere tens of times (compared to diesel fuel) and will reduce the cost of shipping by taking into account the difference in the prices of the first and second energy carriers. Moreover, due to this innovation, the strict environmental safety standards introduced by the International Maritime Organization (IMO) and the responsible governments of the countries will be respected. For example, European ports allow vessels using fuel containing $0.1 \%$ sulphur (Review of Maritime Transport, 2016).

An acceptable alternative is exhaust gases "washing" with an aqueous alkaline solution. We will consider that in scrubbers developed for this operation both sea and fresh water are applied with the same success. The effect is striking: the device holds $99 \%$ of $\mathrm{CO} 2$ and 98\% of solid particles. After final testing of the emission reduction technology, experts expect to achieve one hundred percent compliance with the IMO criteria for the discharge of water used for the intended purpose, while maintaining the work of the main machinery at the same time (Zundkvist, 2011);

b) application of renewable energy sources. So, for example, solar marine systems developed by Eco Marine Power Co. Ltd (Japan) are installed on such large vessels as car transporters, cargo and passenger ferries, oil tankers, not to mention suburban river and pleasure boats (Quick, 2012). The computers, with which they are equipped, follow the best use of the current weather conditions, take care of "folding of sails" and their 
security during a storm;

c) the use of light composites in the vessel construction. They have an impressive weight and strength ratio. Among the most promising is Buckypaper. This is a sheet made of carbon nanotubes. If to make a composite of the corresponding number of these sheets, we get a material 10 times lighter but 500 times stronger than steel (Kaczor, 2008);

d) fastening "air kites"-towers to the stems. They accelerate the movement and, as a result, save fuel. This exotic technique is evidence that specialists continuously think over ways and means of depriving mankind of dependence on energy sources, which, on the one hand, are being exhausted and, on the other, the use of which spoils the environment. Testing of such an auxiliary power (manufacturer - SkySails company) of $600 \mathrm{~m}^{2}$ on Beluga vessel with a deadweight of 20 thousand tons, which carried out a transatlantic sail between Hamburg (Germany) and Guanta (Venezuela), and from there to Mo i Rana (Norway), has shown that the innovation saves fuel on average two thousand dollars a day (Richard, 2008).

\section{The growth of orders for large-scale engineering structures}

Tankers hold the leading positions. The largest of the giants built - Seawise Giant (renamed as Happy Giant, Knock Nevis, and Mont) - had a deadweight of 565 thousand tons. In the container transport sector, MOL Triumph reached a record 20170 TEU. The passenger ship "Harmony of the Seas" invites about seven thousand passengers on board each voyage. And in addition -2100 crew members and service staff.

The main reason for the "gigantomania" is the desire to save on a scale, as with the increase in size, the transportation capacity of vessels grows faster than the construction cost and operating costs together. For example, in order to build a tanker with a deadweight of 550 thousand tons, at least 1.7 times less metal is needed than for 22 vessels of similar designation with a deadweight of 25 thousand tons. The number of its crew will be 20 times smaller, and fuel cost will be lower four times (Narusbayev, 1988). The size of vessels, in turn, determines the tonnage of a certain shipping sector and freight rates. They are an integral part of the price of cargo, and in the future - of goods, whose production depends on the supply of materials, component parts, and semi-finished products.

At the same time, there are also counterarguments for increasing the size of ships. How do such "goliaths" manage to cross not only man-made channels but even natural channels with their limited depths? Where to find investments for the establishment of appropriate infrastructure in the ports that will service them? How do the corresponding costs affect the expected scale effect? Are insurance companies (especially after the 2008 global financial crisis) powerful enough to compensate owners for loss of their vessels or their damage due to a collision, overturn, fire, terrorist act? What are the consequences for the environment in this case ${ }^{1}$ ? The following and many other questions are waiting for the answer.

\section{Reformatting the international shipbuilding specialization}

In the middle of the last century, shipyards of the Old and New Worlds were unconditionally shipbuilding great. But soon they encountered problems, which resulted in the fact that almost two-thirds of the shipyards ceased in Europe, which led to the job loss of hundreds of thousands of people. The response to the latest challenges and threats by competitors has been large-scale innovation diversification measures that have made it possible to open or strengthen positions in the following market segments:

innovative and premium ships. In particular, ocean yachts, ferries, cruise liners, research vessels, roll-on/ roll-off ships, chemical carriers, offshore and "blue" ships. At the last, harmful emissions to the atmosphere and into seawater have been eliminated, fuel-saving technologies have been introduced. This is motivated by special programs of a holistic approach to engineering and building of environmentally friendly objects, started in particular in the European Union. Among their participants - ship, classification societies, research institutions, and institutions of higher education;

wind parks They are created with such intensity that some ships have completely reoriented themselves on the installation of offshore wind generators and their maintenance.

From a number of organizational innovations, we draw attention to the spread in the countries of our continent as an effective tool as it turned out as clusters. Since the creation of the European Network of Maritime Clusters, it has been 13 years since. Today it covers more than ten national marine clusters: Sea Vision UK (Great Britain), Bundesministerium für Wirtschaft und Technologie (Germany), Cluster Maritime Français (France), Federazione del Mare (Italy), Clúster Marítimo Español (Spain), and others. By their structure, almost all of them integrate the following activities:

design, construction, maintenance, repair, and modernization of vessels and other floating marine structures;

manufacture and sale of all kinds of equipment for ships and other marine floating facilities and structures;

financial, legal, technological, port, and logistics activities, ship's agency service;

exploitation of vessels, floating marine structures,

\footnotetext{
${ }^{1}$ The cost of cleaning only the water area and the coast after the explosion on the Prestige tanker was 12 billion USD (Prestige Oil Spill, 2008)
} 


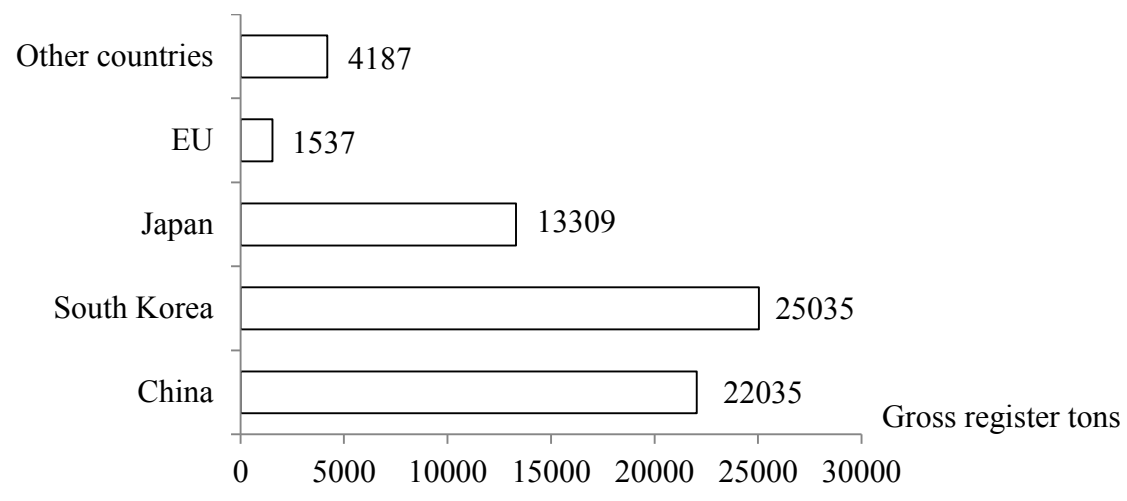

Figure 2. Leading shipbuilding countries

Source: the statistics Portal, 2018

drilling platforms.

Unlike the industry form of business organization known from the past, modern industrial clusters are characterized by high innovation that feeds the roots in the informal integration of large companies with a great number of small and medium enterprises, technology centres, engineering firms, which cooperate within the framework of a joint value chain.

As a result of considerable efforts, now 300 shipyards have enough orders, which provide work more than 500 thousand workers. Their efforts generate income that amounts to about 30-40 billion euros per year (Lo C., 2013). As for tankers, ships for general cargoes, container carriers, their construction is mainly concerned with China, South Korea, Japan. Together, though not negotiating this, they turned the Asia-Pacific region into a new centre of world shipbuilding (Figure 2).

A characteristic feature of the last decade was the emergence of shipbuilding business in developing countries: Algeria, Bangladesh, Vietnam, India, Indonesia, Malaysia, the Philippines. Most concentrated their efforts on small and medium-sized facilities and has already managed to serve export markets. For example, Singapore specializes in support and supply vessels, dredgers, yachts, research vessels. Their main competitive advantages are:

cheap labour. Even cheaper (who could have thought!) than in China;

government support. In Malaysia, ships are exempt from taxes on the import of components and on sale. In 2015, the Shipbuilding/Ship Repair Industry Strategic Plan was approved here, which aims to ensure control of two percent of the world's shipbuilding by 2020 (Fardaus, 2014).

Some shipyards seek economic unions with more experienced international partners. In this context, attention is drawn to the beginning of the release of Vietnamese German and Japanese licensed ship facilities: Wärtsilä, MAN Diesel, and Mitsubishi.

The list of states that are rapidly increasing the volume of trade by newly built ships has increased due to Brazil, Mexico, and Venezuela, which gives grounds for attributing Latin America to applicants for the participation in competitions for the commitment of shipowners in the most attractive market segments. Brazil, for example, sees prospects in the construction of oil platforms and vessels of the offshore sector.

The real shipbuilding boom that swept the world's "newcomers" did not leave indifferent foreign investors. Among the most active are:

shipbuilding firms. They are attracted, firstly, by a low cost of production; and secondly, an increase in demand for shipping services, which increases the portfolio of contracts. In 2015, China has directed 10.9 billion USD in Indonesian shipbuilding. This is only a share of 63 billion USD planned to be spent on infrastructure development in the archipelago country (Grey, 2015); shipping companies. Their motivation is more branched out. On the one hand, the desire to increase control over the suppliers of their fixed capital. On the other hand, the desire to take advantage of the vertical integration of own business with the potential of the shipyard ${ }^{2}$. And, finally, savings on a scale. It is noteworthy that shipyards-newcomers have the ability to learn and increasingly apply for orders for high-tech facilities, which may mean the loss of Europeans' best card in a competitive struggle.

\section{Conclusions}

1. The world economy does not have any chance to exist and develop without shipbuilding, the enterprises of which produce a number of complex engineering structures. Each ofthemservesaspecifickindofeconomicactivity.Atthesame time, the shipyards' load depends on the business activity. Its increase causes extraordinary demand, requires the

\footnotetext{
${ }^{2}$ Under the agreement between the South Korean Hanjin Heavy Industries, a part of the holding company Hanjin Group, and the largest shipping company of France CMA CGM Group, not in Japan and not in China, but in the Philippines, three of the world's largest container carriers with a capacity of 20 thousand TEU will be built (Grey, 2015)
} 
intensification of their movement from the warehouses of finished goods to the places of consumption. Simultaneously, deceleration of the business activity entails postponement of purchases, inhibition of sales, negatively affects the work of shipyards. This pattern should be predictable both by rulers and corporate management.

2. The relentless pursuit of capital for expanded reproduction was the result of shifting the centre of gravity of world shipbuilding from Europe and the USA to the Far East, to South-East Asia, and Latin America. Those who were contemptuously considered as "emerging" quickly turned from outsourcers into independent players in the shipbuilding markets, creating a fair competition for investor countries. It was not just an unexpected surprise, but immediately affected the mood of shipowners, who were attracted by relatively cheap means of sea transport. Especially superfluous. The benefit turned out to be double since the scale effect also showed itself. In turn, Europe and the USA were faced with the closure of shipbuilding enterprises, the disappearance of jobs, and the bursts of social discontent among coastal residents.

3. If this had happened in the IX or even the early XX century, an economic confrontation would likely lead to the resumption of the status quo by military means. Meanwhile, the world has changed confident that the future belongs to them! significantly and civilized methods of confrontation were invented to counter self-created rivals. The first of these was the proclamation of the relevance of the serious attitude towards environmental protection. Especially since it actually fell under the threat of irreversible negative consequences for human life. This has created an industry that has not been seen before - the offshore industry, in that part that is related to alternative energy.

The second counterpoint was the emphasis made on the use of innovative technologies at all stages of the lifecycle of shipbuilding products. By their help: a) the time and cost of construction of vessels aligned, in comparison with the "oriental tigers"; b) the market received an unprecedented offer, which constitutes the unique competitive advantage of the EU and the United States. How long - time will show.

4. World experience - not fun to take pleasure or to fear. World experience is, above all, a great opportunity to make sound conclusions, gain wisdom, learn from others' mistakes or positive achievements. It is obvious that power and business during the time of Ukraine's existence as an independent state failed even to preserve, much less improve shipbuilding. This does not mean, by the way, that everything is lost. Appropriate beliefs feed the activities of the new generation of shipyards. We are

\section{References:}

CEEH (2011). Scientific Report № 3. Assessment of Health-Cost Externalities of Air Pollution at the National Level using the EVA Model System. Centre for Energy, Environment and Health Report series. Retrieved from: http://ceeh.dk/CEEH_Reports/Report_3/CEEH_Scientific_Report3.pdf

Developments in International Seaborne Trade- $-\bar{R}$ eview of Maritime Transport (2016). Chapter 1. United Nations publication. Retrieved from: http://unctad.org/en/PublicationsLibrary/rmt2016_ru.pdf

Fardaus, F. (2014). Potentials of shipbuilding industry. Retrieved from: https://bdnews24.com/ business/2014/01/15/potentials-of-shipbuilding-industry

Grey, E. (2015). Southeast Asia's shipbuilding evolution. Retrieved from: https://www.ship-technology.com/ features/featuresoutheast-asias-shipbuilding-evolution-4572766/

Narusbayev, A. A. (1988). Shipbuilding of XXI century. - L.: Shipbuilding.

Hodson, H. (2014). Robotic suit gives shipyard workers super strength. Retrieved from: https://www.newscientist.com/ article/ mg22329803.900-robotic-suit-gives-shipyard-workers-super-strength\#.U-BkmKPrzPx

Hossain, K. A., Zakaria, N. M. G. (2017). A Study on Global Shipbuilding Growth, Trend and Future Forecast. Procedia Engineering, 194, 247-253.

Kaczor, B. (2008). Future planes, cars may be made of «buckypaper». Retrieved from: https://usatoday30.usatoday.com/tech/science/discoveries/2008-10-17-buckypaper_N.htm

Lo, C. (2013 ). Blue growth: keeping Europe's shipyards afloat. Retrieved from: http://www.ship-technology.com/ features/featureblue-growth-keeping-europe-shipyards-afloat/

Nikiforov, V. G., Nesluhov, D. S. (2011). Modern trends in the development of the world shipbuilding shake from the standpoint of the theory of economic cycles. The branch and regional economics: problems of management and solutions, 1, 101-105.

Parsyak, V. N., Soleswick, M. B. (2014) Integration of marine engineering and information and communication technologies. Shipbuilding and marine infrastructure, 2, 144-155.

Prestige Oil Spill (2008). Top 10 most expensive accidents in history. Retrieved from: http://www.wreckedexotics.com/ articles/011.shtml

Quick, D. (2012). EnergySails harness wind and solar power to cut ship fuel consumption. Retrieved from: http://newatlas.com/eco-marine-power-energysail-solar-sails/25005/

Richard, M. G. (2008). Cargo Ship with Kites: First Trans-Atlantic Trip a Success! Retrieved from: https://www.treehugger.com/cars/cargo-ship-with-kites-first-trans-atlantic-trip-a-success.html 
Review of maritime transport. United Nations conference on trade and development (UNCTAD). (2017). Retrieved from: http://unctad.org/en/PublicationsLibrary/rmt2017_en.pdf

Seroka-Stolka, O. (2014). The Development of Green Logistics for Implementation Sustainable Development Strategyin Companies. Retrieved from: https://www.sciencedirect.com/science/article/pii/S1877042814054706 Shipbuilding Industry-Statistics \& Facts (2017). Retrieved from: https://www.statista.com/topics/3712/ shipbuilding-industry/

The statistics Portal (2018). Regional breakdown of the global shipbuilding market. Retrieved from: https://www.statista.com/statistics/263399/regional-breakdown-of-the-global-shipbuilding-market-by-contracting/

Zundkvist, L. (2011). Reducing emissions from marine vessels. Retrieved from: http://www.maritimemarket.ru/ article.phtml?id=1351 